\title{
Education-job Fit and Work-related Learning of Recent Graduates: \\ Head Start or Filling a Gap?
}

For many young adults, entering a first job after graduation is experienced as an important turning point in their lives. The alignment of this first job and graduates' education appears to be of key influence and prior research highlighted various effects of the fit between the educational background of graduates and their first job (Groot \& Maassen van den Brink, 2000). Work-related can be argued to be one of the key outcomes of fit. While all graduates entering their first job learn in some way at work, their experienced fit situation has been argued to strongly affect their learning behavior (Brunello, 2004). However, in what way fit influences learning at work remains up for debate. Two contradicting processes are put forward to explain the relationship between educationjob fit and work-related learning: A complementary and substitution process are suggested (Brunello, 2004). This study aims to empirically assess these contradicting explanations for the relationship between education-job fit and work-related learning of recent graduates.

\section{Theoretical Framework}

\section{Education-Job Fit}

Vertical and horizontal fit. Vertical fit includes the degree to which graduates' educational level fits the optimal educational level required for their current job (Leuven \& Oosterbeek, 2011). Horizontal fit includes the degree to which employees' field of study is in line with the optimal field of study to execute their job (Verhaest, Sellami, \& Van der Velden, 2017). Although outcomes of education-job fit are mostly investigated in relation to vertical fit, previous research demonstrated that the combination of vertical and horizontal fit can have additional effects (Robst, 2007; Verhaest et al., 2017). Consequently, it is crucial to not only take vertical fit into account when aiming to investigate the effects of fit, but to consider the conjoint effects of different types of fit.

Measuring education-job fit. The reported incidence of vertical and horizontal misfit varied strongly across different studies (Heijke, Meng, \& Ris, 2003; Teichler, 2007). These wide varieties in the incidence of fit may partially be explained by the variety in ways in which fit is measured. Leuven and Oosterbeek (2011) discerned different measurements of fit. A first measure is often referred to as a subjective method, including a self-assessment approach that questions employees about the requirements of their job. A second way of measuring fit is considered to be a more objective method. This method starts from a description of employees' job and their educational background, which are classified by an external rater to decide on employees' fit.

\section{Work-Related Learning in the Transition to Work}


Education is expected to prepare students to enter the labor market successfully (Robst, 2007). However, educational programs can never provide graduates with all necessary competences, especially because of the level of flexibility that is expected nowadays (Teichler, 2007). This indicates how (the need for) learning does not stop after graduation. This work-related learning is defined by Kyndt and Baert (2013) as participation in learning activities that can be either formal or informal, which lead to an improvement of competences and eventually contribute to individuals' and/or organizational performance. A specific component of this definition points to the nature of the learning activities that can be formal or informal. Formal learning activities are those activities that are structured and planned in time, for which the goals are clear (e.g., seminars). Informal learning activities are embedded in daily work and are generally less structured (e.g., discussing problems with colleagues) (Kyndt \& Baert, 2013). In order to get a more fine-grained view on the role of workrelated learning in the transition to work, it is essential to consider a broad range of both formal and informal learning activities (Berg \& Chyung, 2008).

\section{Relationship between Fit and Work-Related Learning}

The idea that education-job fit and work-related learning are complementary and that learning complements an already existing and appropriate set of competences goes back to the human capital theory (Becker, 1964). It is assumed that graduates' human capital is mainly represented by their knowledge and skills acquired within education (Wolbers, 2003). This built-up human capital enables graduates to further develop their competences and is argued to stimulate the participation in work-related learning activities. Human capital theory assumes that additional learning is easier when the correct set of skills is available, supporting the complementing hypothesis (Brunello, 2004). Although this is coined theoretically, it has rarely been investigated. Most studies find support for this hypothesis when comparing different educational levels (i.e., related to vertical fit issues; Brunello, 2004; Verhaest \& Omey, 2013).

The substitution hypothesis starts from the premise that work-related learning could replace the educational function and fill a gap between recent graduates educational background and the knowledge and skills required for the job (Heijke et al., 2003). Following this reasoning, employees would participate in learning activities because they experience a need to acquire or improve competences in order to perform in their job (Verhaest \& Omey, 2013). Again, there is limited empirical research available testing this hypothesis. Two studies confirmed the substitution hypothesis for formal work-related learning activities in the case of horizontal fit (Heijke et al., 2003; Van Smoorenburg \& van der Velden, 2000). 


\section{Present Study}

The current study aims to empirically assess the contradicting explanations for the relationship between education-job fit and work-related learning of recent graduates. The focus will be on gaining understanding how different fit profiles are manifested. By combining four measurements of fit (vertical subjective fit, vertical objective fit, horizontal subjective fit, and horizontal objective fit), this study takes a broad view on the fit profile of recent graduates.

$R Q 1$. Which education-job fit profiles can be found among recent graduates?

Furthermore, the study aims to gain more insight into the relationship between the different education-job fit profiles and the learning behavior of recent graduates. The complementing and substituting hypotheses in relation to understanding the relationship between education-job fit and work related learning are tested, assessing the impact of fit on both formal and informal learning.

$R Q 2 a$. Do participants in different fit profiles report different learning behavior?

However, as the entrance to a new job implies additional opportunities to learn new things (Grosemans et al., 2017), we will investigate whether (possible) differences are sustained six months later in the job of recent graduates.

$R Q 2 b$. Are these differences in learning behavior sustained six months later into the job?

\section{Method}

\section{Procedure and Participants}

The data collection focused on recent graduates from different higher education institutions in Flanders (Belgium). The graduates were surveyed in November 2016 (T1), approximately four months after graduation. A total of $\mathbf{7 7 9}$ graduates were included in this study. Six months after this survey, participants were asked to complete the survey again (May 2017; T2): 398 participants remained in the same job at $\mathrm{T} 2$ and were used in the analyses to answer research question $2 \mathrm{~b}$.

\section{Instruments}

Concerning subjective fit, we opted for a direct self-assessment question relating to the requirements of the job (Leuven \& Oosterbeek, 2011). Objective fit was assessed by means of a job analysis (Leuven \& Oosterbeek, 2011). Graduates' employment was classified based on the International Standard Classification of Occupations (ISCO; International Labour Office, 2012). Their educational background was classified in accordance with the International Standard Classification of Education (ISCED; UNESCO Institute for Statistics, 2012, 2014). Afterwards, both ISCO and ISCED codes were combined in order to make a correct estimation of objective fit. 
To measure participation in work-related learning activities, the 13-item instrument of Authors et al. (2018) was used. All items were measured on a 7-point Likert scale, ranging from never to on a daily basis.

\section{Analyses}

It was examined which fit profiles are occurring in practice, based on all four measures of fit simultaneously using person-centered analyses. A latent profile analysis (LPA) was chosen to capture patterns in the data (Muthen, 2001). Different models ranging from one to six profiles were compared using maximum likelihood robust estimation (MLR).

Following the identification of the profiles, differences in work-related learning were examined by means of the three-step procedure as described by Asparouhov and Muthén (2014). Differences between these means were compared by using the Wald chi-square statistic. The stability of the differences in learning behavior after six months was examined by means of a latent change score model (LCSM; McArdle \& Nesselroade, 2014). All latent analyses were conducted using the Mplus software (version 8.1.5).

\section{Results}

\section{Education-Job Fit Profiles}

The different education-job fit profiles were estimated by using a LPA, ranging from one to six profiles. Based on the theoretical meaningfulness of the provided profiles the solution with four profiles was identified as the most optimal solution, which was supported by the BIC value, the LMR test, and the BLRT (see Table 1). The results for the four profiles are presented in Table 2. Taking a closer look at each profile separately indicates that graduates in the first profile are clearly typified by high scores on subjective fit for both vertical and horizontal fit. Moreover, graduates in this profile have the highest probability of being objectively classified as having a well-fitting job. Therefore, this first profile is named the full fit profile. The second profile is also characterized by a relatively high score on horizontal subjective fit. This is also reflected in the objective measure of horizontal fit, as $70 \%$ of the graduates in this profile were classified as having a horizontal objective fit. Therefore, this profile is labeled the horizontal fit profile. In contrast to the second profile, the third profile reported a high score on vertical subjective fit and a low score on horizontal subjective fit. Their main distinguishing feature clearly is the high score on vertical subjective fit, being the reason why this profile is referred to as the vertical fit profile, despite the lower values on vertical objective fit. Graduates in the final profile indicate low scores on all four of the measures of fit. Consequently, this final profile is labeled the full misfit profile. 


\section{Relationship between Fit and Work-Related Learning}

As a next step, it was examined whether differences were found in work-related learning for these profiles. The means of the factors of work-related learning for each profile are shown in Table 3. Results demonstrated that differences between the profiles were meaningful (Wald $\chi^{2}(9)=36.20$; $p<.001$ ). Follow-up tests indicated that significant differences could be found for formal learning activities (Wald $\chi^{2}(3)=20.35 ; p<.001$ ) and for informal learning activities using personal sources (Wald $\left.\chi^{2}(3)=15.01 ; p<.01\right)$. The Wald-statistic $(d f=3)$ equaled 5.57 for informal learning activities using environmental sources, which was not significant $(p>.05)$.

With respect to the last research question, the latent change of work-related learning from T1 to T2 was modeled. The average change per profile for the three factors of work-related learning is presented in Table 4 . None of the change factors was significant, indicating that the average learning behavior did not change for any of the four profiles.

\section{Conclusion}

In conclusion, this study aimed to get a deeper insight in the relationship between education-job fit and work-related learning. Four profiles could be identified, demonstrating that vertical and horizontal fit can both be present (full fit profile), both be absent (full misfit profile), or one of them can be present (horizontal fit profile and vertical fit profile). Relating these profiles to work-related learning provided evidence for the complementing hypothesis, which starts from the idea that continued learning at work complements what was learned in higher education. A more fine-grained insight in the relationship was provided by taking both formal and informal learning activities into account. The level of education mattered for formal learning: The complementing hypothesis was confirmed for graduates for whom there was vertical fit. For informal learning activities using personal sources, we found that especially horizontal fit was of importance: Graduates who were employed in a domain that was in line with their study domain reported more informal learning using personal sources. Investigating this relationship six months later into the job revealed no differences in work-related learning, indicating that the relationship stayed the same during the first months into the job. 


\section{References}

Author et al. (2018). Development and validation of a questionnaire measuring work-related learning. Manuscript Submitted for Publication.

Asparouhov, T., \& Muthén, B. (2014). Auxiliary variables in mixture modeling: Three-step approaches using Mplus. Structural Equation Modeling, 21, 329-341. doi:10.1080/10705511.2014.915181

Becker, G. S. (1964). Human capital: A theoretical and empirical analysis with special reference to education. New York, NY: NBER.

Berg, S. A., \& Chyung, S. Y. (2008). Factors that influence informal learning in the workplace. Journal of Workplace Learning, 20, 229-244. doi:10.1108/13665620810871097

Brunello, G. (2004). Labour market institutions and the complementarity between education and training in Europe. In D. Checchi and C. Lucifora (Eds.), Education, training and labour market outcomes in Europe (pp. 188-209). Londen: Palgrave.

Groot, W., \& Maassen van den Brink, H. (2000). Overeducation in the labor market: A meta-analysis. Economics of Education Review, 19, 149-158. doi:10.1016/S0272-7757(99)00057-6

Grosemans, I., Coertjens, L, \& Kyndt, E. (2017). Exploring learning and fit in the transition from higher education to the labour market: A systematic review. Educational Research Review, 21, 67-84. doi:10.1016/j.edurev.2017.03.001

Heijke, H., Meng, C., \& Ris, C. (2003). Fitting to the job: The role of generic and vocational competencies in adjustment and performance. Labour Economics, 10, 215-229. doi:10.1016/S0927-5371(03)00013-7

International Labour Office (2012). International standard classification of occupations, ISCO-08.

Retrieved from http://www.ilo.org/wcmsp5/groups/public/---dgreports/---dcomm/--publ/documents/publication/wcms_172572.pdf

Kyndt, E., \& Baert, H. (2013). Antecedents of employees' involvement in work-related learning: A systematic review. Review of Educational Research, 83, 273-313. doi:10.3102/0034654313478021

Leuven, E., \& Oosterbeek, H. (2011). Overeducation and mismatch in the labor market. In E. Hanushek, S. Machin, \& L. Woessman (Eds.), Handbook of the economics of education 4 (pp. 283-326). Amsterdam: North Holland.

McArdle, J. J., \& Nesselroade, J. R. (2014). Longitudinal data analysis using structural equation models (Washington). American Psychological Association.

Muthen, B. O. (2001). Latent variable mixture modeling. In G. A. Marcoulides \& R. E. Schumacker (Eds.), New Developments and Techniques in Structural Equation Modeling (pp. 1-33). 
Mahwah, NJ: Lawrence Erlbaum Associates.

Robst, J. (2007). Education and job match: The relatedness of college major and work. Economics of Education Review, 26, 397-407. doi:10.1016/j.econedurev.2006.08.003

Teichler, U. (2007). Does higher education matter? Lessons from a comparative graduate survey. European Journal of Education, 42, 11-34. doi:10.1111/j.1465-3435.2007.00287.x

UNESCO Institute for Statistics (2014). ISCED Fields of Education and Training 2013 (ISCED-F 2013).

Retrieved from http://dx.doi.org/10.15220/978-92-9189-150-4-en

UNESCO Institute for Statistics (2012). International Standard Classification of Education, ISCED 2011. Retrieved from http://uis.unesco.org/sites/default/files/documents/internationalstandard-classification-of-education-isced-2011-en.pdf.

Van Smoorenburg, M. S. M., \& van der Velden, R. K. W. (2000). The training of school-leavers: Complementary or substitution? Economics of Education Review, 19, 207-217. doi:10.1016/S0272-7757(99)00044-8

Verhaest, D., \& Omey, E. (2013). The relationship between formal education and skill acquisition in young workers' first jobs. The Manchester School, 81, 638-659. doi:10.1111/j.14679957.2012.02305.x

Verhaest, D., Sellami, S., \& van der Velden, R. (2017). Differences in horizontal and vertical mismatches across countries and fields of study. International Labour Review, 156, 1-23. doi:10.1111/j.1564-913X.2015.00031.x

Wolbers, M. H. J. (2003). Job mismatches and their labour-market effects among school-leavers in Europe. European Sociological Review, 19, 249-266. 
Table 1

Goodness of Fit for the Different Models

\begin{tabular}{ccccc}
\hline $\begin{array}{c}\text { Number of } \\
\text { profiles }\end{array}$ & $\begin{array}{c}\text { Entropy } \\
\text { Criterion (BIC) }\end{array}$ & $\begin{array}{c}\text { Bayesian } \\
\text { Information } \\
\text { Likelihood Test (LMR) }\end{array}$ & $\begin{array}{c}\text { p-value Vuong-Lo- } \\
\text { Mendell-Rubin }\end{array}$ & $\begin{array}{c}\text { p-value Bootstrap } \\
\text { Likelihood Ratio Test } \\
\text { (BLRT) }\end{array}$ \\
\hline 1 & - & 7748.47 & - & - \\
2 & .93 & 7242.69 & $<.001$ & $<.001$ \\
3 & .88 & 7163.18 & .023 & $<.001$ \\
4 & .93 & 6989.66 & $<.001$ & $<.001$ \\
5 & .79 & 6924.26 & .029 & $<.001$ \\
6 & .83 & 6894.48 & .11 & $<$ \\
\hline
\end{tabular}


Table 2

Results and 90\% Confidence-Intervals of the LPA with Four Profiles

\begin{tabular}{lcccc}
\hline & $\begin{array}{c}\text { Profile } 1 \\
\text { Full fit }\end{array}$ & $\begin{array}{c}\text { Profile } 2 \\
\text { Horizontal fit }\end{array}$ & $\begin{array}{c}\text { Profile } 3 \\
\text { Vertical fit }\end{array}$ & $\begin{array}{c}\text { Profile 4 } \\
\text { Full misfit }\end{array}$ \\
\hline Vertical objective fit & .56 & .50 & .34 & .14 \\
& {$[.52 ; .59]$} & {$[.40 ; .60]$} & {$[.24 ; .45]$} & {$[.02 ; .25]$} \\
Horizontal objective fit & .77 & .70 & .52 & .23 \\
& {$[.74 ; .80]$} & {$[.61 ; .80]$} & {$[.42 ; .63]$} & {$[0.09 ; .36]$} \\
Vertical subjective fit & 6.01 & 2.89 & 5.15 & 1.97 \\
Horizontal subjective fit & 6.02 & {$[2.68 ; 3.09]$} & {$[4.94 ; 5.36]$} & {$[1.65 ; 2.29]$} \\
& {$[5.96 ; 6.09]$} & {$[4.62 ; 5.23]$} & {$[2.68 ; 3.25]$} & {$[1.41 ; 2.02]$}
\end{tabular}

Note. Subjective fit displays the mean of the profile for the measures on a 7-point Likert scale. Objective fit displays the probability for each profile to be classified in the fit-condition. 
Table 3

Means of Work-Related Learning for Different Education-Job Fit Profiles at T1

\begin{tabular}{|c|c|c|c|c|}
\hline & & Formal learning & $\begin{array}{l}\text { Informal learning - } \\
\text { personal sources }\end{array}$ & $\begin{array}{l}\text { Informal learning - } \\
\text { environmental sources }\end{array}$ \\
\hline & $N(\%)$ & $M(S E)$ & $M(S E)$ & $M(S E)$ \\
\hline Full fit & 583 (74.84\%) & $2.54^{a}(0.06)$ & $5.58^{\mathrm{a}, \mathrm{d}}(0.05)$ & $4.85(0.06)$ \\
\hline Horizontal fit & $82(10.53 \%)$ & $2.31^{\mathrm{b}}(0.13)$ & $5.53^{\mathrm{e}}(0.12)$ & $4.61(0.17)$ \\
\hline Vertical fit & 73 (9.37\%) & $2.74^{c}(0.17)$ & $5.28(0.11)$ & $4.63(0.17)$ \\
\hline Full misfit & $41(5.26 \%)$ & $1.96(0.14)$ & $5.02(0.18)$ & $4.47(0.25)$ \\
\hline
\end{tabular}


Table 4

Means of Change Scores of Work-Related Learning for Different Education-Job Fit Profiles

\begin{tabular}{lllll}
\hline & & Formal learning & $\begin{array}{l}\text { Informal learning }- \\
\text { personal sources }\end{array}$ & $\begin{array}{l}\text { Informal learning - } \\
\text { environmental sources } \\
\end{array}$ \\
& $N(\%)$ & $M(S E)$ & $M(S E)$ & $M(S E)$ \\
\hline Full fit & $315(79.15 \%)$ & $-0.11(0.06)$ & $-0.01(0.07)$ & $-0.07(0.10)$ \\
Horizontal fit & $30(7.54 \%)$ & $-0.12(0.45)$ & $0.07(0.24)$ & $0.53(0.66)$ \\
Vertical fit & $39(9.80 \%)$ & $0.25(0.35)$ & $0.10(0.20)$ & $0.25(0.42)$ \\
Full misfit & $14(3.52 \%)$ & $-0.04(0.19)$ & $-0.05(0.33)$ & $-0.64(0.55)$ \\
\hline
\end{tabular}

